\title{
KNOWLEDGE, OPINION AND ATTITUDES TOWARDS ADVERSE DRUG REACTIONS REPORTING AMONG PHARMACY STUDENTS IN ROMANIA
}

\author{
ANDREEA FARCAȘ ${ }^{1 \#}$, CAMELIA BUCȘA ${ }^{1 *}$, ANDA CRIȘAN $^{1 \#}$, IRINA CAZACU $^{1}$, DANIEL \\ LEUCUȚA $^{2 \#}$, CRISTINA MOGOȘAN ${ }^{1}$ \\ ${ }^{I}$ Drug Information Research Center, "Iuliu Hatieganu” University of Medicine and Pharmacy, Cluj-Napoca, Romania \\ ${ }^{2}$ Medical Informatics and Biostatistics Department, "Iuliu Haţieganu” University of Medicine and Pharmacy, Cluj-Napoca, \\ Romania
}

*corresponding author: cfarah@umfcluj.ro

${ }^{\#}$ Authors with equal contribution.

\begin{abstract}
Pharmacists' contribution to adverse drug reactions (ADRs) reporting is very low in Romania. Knowledge, opinion and attitudes on ADRs reporting and pharmacovigilance (PV) were tested in an e-survey on social media among pharmacy students in Romania, based on an anonymous questionnaire. 138 students from 9 pharmacy faculties participated in the survey. 58.7\% were students in their final years of study. Among all students, $92 \%$ planned to report ADRs as future pharmacists, but only $48 \%$ of students in their last (fifth) year and $37 \%$ in their fourth year considered themselves prepared/ready to report. Overall, less than half $(45.7 \%)$ of the students have studied PV, and $95 \%$ of all agreed that PV should be included in their curricula as a separate course. Most of the students (94\%) knew that they could report ADRs to the National Competent Authority. Students considered that serious (94\%), unknown (90\%) ADRs and those related to a new medicine (90\%) should be reported. Most students considered that the purpose of ADRs reporting is patient safety (85\%) and detection of unknown ADRs (84\%). 80\% considered that ADRs reporting should be mandatory.
\end{abstract}

\section{Rezumat}

În România, contribuția farmaciștilor la raportarea reacțiilor adverse (RA) ale medicamentelor este foarte scăzută. Cunoștințele, opinia și atitudinile cu privire la raportarea RA și farmacovigilență (FV) au fost testate printr-un sondaj online în rândul studenților farmaciști din România, pe baza unui chestionar anonim. Au participat 138 de studenţi de la 9 facultăți de farmacie. $58,7 \%$ au fost studenți în ultimii doi ani de studiu. Dintre toți studenții, 92\% intenționează să raporteze RA ca viitori farmaciști, dar doar $48 \%$ dintre studenții din ultimul an și $37 \%$ din al patrulea an s-au considerat pregătiţi să raporteze. Mai puţin de jumătate dintre studenți $(45,7 \%)$ au studiat FV şi $95 \%$ consideră că FV ar trebui să fie inclusă în programa universitară. Majoritatea studenților (94\%) știau că pot raporta RA Autorității Naționale Competente. Studenții au considerat că RA grave (94\%), necunoscute $(90 \%)$ și cele asociate unui medicament nou $(90 \%)$ ar trebui raportate. Majoritatea studenților au considerat că scopul raportării RA este siguranța pacienților (85\%) și detectarea RA necunoscute $(84 \%) .80 \%$ au considerat că raportarea RA ar trebui să fie obligatorie.

Keywords: adverse drug reactions, spontaneous reporting, pharmacy students, pharmacovigilance, education

\section{Introduction}

In Europe, the burden of adverse drug reactions (ADRs) can be substantial in both out-patient and in-patient settings, as ADRs are responsible for up to $3.5 \%$ of hospital admissions and affect up to $10.1 \%$ of hospitalized patients [3]. Therefore, post-marketing surveillance of drugs' safety is an important part of pharmacovigilance (PV), with the primary purpose of improving public health by preventing and reducing the number of ADRs.

Spontaneous ADRs reporting systems (SRS), first established in the 1960s, still represent a valuable source for detecting unknown, rare and serious ADRs related to new and well-established medicines and for safety signals [14].

The success or failure of SRS depends on the proactive attitude of the reporters, healthcare professionals (HCPs) and patients. Under-reporting is common and represents the main downside of these systems while motivating HCPs and patients to report ADRs is a constant challenge for healthcare authorities $[11,12]$. To improve the efficiency of the SRS, HCPs should have sufficient knowledge and positive attitudes towards reporting ADRs, while also acknowledging the importance of PV when it comes to patients' safety. Within this scope, PV undergraduate education is essential for future HCPs in order to acquire adequate 
knowledge and competencies to recognize, manage and report ADRs [17, 20].

Community and hospital pharmacists can contribute to the safe use of drugs and PV. Community pharmacists can have a substantial role in ADR reporting as they are in a unique position for detection of ADRs in a large number of patients while dispensing and counselling them. Additionally, hospital pharmacists can play a role in reporting serious ADRs, given that ADRs are often responsible for hospital admission or hospital prolongation [4, 7, 21]. However, the knowledge, attitudes and contribution of pharmacists with regard to ADR reporting vary significantly among countries [10].

Several studies carried out in other countries have shown that, while most medical and pharmacy students recognize the importance of ADRs reporting and express their willingness to report, they have insufficient knowledge on PV and ADR reporting [1, 8, 9, 15, 18]. Therefore, these results, as well as the lack of data on the subject in future Romanian pharmacists and the very low contribution of pharmacists to ADRs reporting in Romania, encouraged the development of the present study [16]. The main aim was to investigate the knowledge, opinion and attitudes towards ADRs reporting among pharmacy students in Romania.

\section{Materials and Methods}

We conducted a cross-sectional survey among pharmacy students from Romania between April and August 2019. The survey addressed all pharmacy students who attended one of the Faculties of Pharmacy in Romania at the time of the study, regardless of their year of study. The e-survey was launched in April during the National Congress of Pharmacy Students, followed by an online promotion on social media done by the Federation of Pharmacy Students Association in Romania (Federaţia Asociaţiilor Studenţilor Farmacişti din România - FASFR). For the latter, one initial promotion of the e-survey was conducted, followed by two reminders.

The survey was based on a questionnaire developed to test pharmacy students' attitudes, opinion and knowledge on ADRs reporting and PV. The questionnaire was anonymous, and it comprised 27 mandatory questions. The questionnaire was adapted according to previous similar research that measured knowledge, attitude and perception about PV and ADR reporting, while some of the questions were related to the Romanian PV system. An information letter explaining the study objectives and the voluntary participation in the survey preceded the questionnaire. The survey was designed in four sections. The first one included eight questions that assessed the students' opinion on the importance of ADRs reporting and PV training during faculty years and on their preparedness/ readiness to report ADRs. The opinion was measured on a 5-point Likert scale ( $1=$ strongly disagree to $5=$ strongly agree). The second and third sections of the questionnaire were designed to evaluate the students' knowledge about ADRs reporting (e.g., where to report, who can report, what ADRs to report, what happens with reported ADRs) and on the purpose of ADR reporting and its effects in terms of medicines prescription and regulation. Dichotomous questions or multiple-choice questions measured knowledge. The last section included questions on demographics such as age, gender, current university and questions on whether the students had any PV knowledge before participating in the survey. After filling in the questionnaire, the students could access a link that offered them more information regarding ADRs reporting and the importance of PV. The participation was voluntary and anonymous, the consent being given by filling in the questionnaire after reading the information letter at the beginning of the survey; therefore, the study needed no approval by an Ethics Committee. Qualitative answers were described with absolute and relative frequencies. Relations between qualitative variables were checked with Chi-squared test, or the Fisher exact test (in case the expected frequencies of at least $20 \%$ of the cells had values under 5 , or any expected frequencies was below 2). To further assess the relation between knowledge and possible predictive factors, we used simple and multiple regression analyses. The dependent variable was computed as the mean of the percentage of correct answers to four selected questions, regarding knowledge. First, we fitted simple linear models, and then we fitted the multiple regression model. For each model we checked their assumptions: the normality of the residuals (with a quantile quantile plot), the heteroskedasticity (with Breusch Pagan test, as well as with a scale location chart: fitted values vs. standardized residuals), the functional form (with component + residual plots). For the multiple regression model we assessed the multicollinearity (with variance inflation factors). The results of the regression were presented as unstandardized regression coefficients, with $95 \%$ confidence intervals, and associated p-values. For all statistical tests, a p-value less than 0.05 was considered statistically significant, and we computed the two-tailed p-values. All statistical computations were performed with the $\mathrm{R}$ environment for statistical computing and graphics (R Foundation for Statistical Computing, Vienna, Austria), version 4.0.2.

\section{Results and Discussion}

In total, 138 students from 9 Pharmacy Faculties in Romania participated in our survey. The vast majority of students $(89.1 \%)$ were aged between 20 and 24 years, while the remaining $10.9 \%$ were aged less than 20 years $(5.1 \%)$, between 25 and 30 years $(5.1 \%)$ or 
above 30 years $(0.7 \%)$. Most of the participants were female students $(89.9 \%)$. The number of participating students increased with their year of study, $7.2 \%$ being in their first year, $10.1 \%$ in the second year, $23.9 \%$ in the third year, $26.8 \%$ in the fourth year and $31.9 \%$ in the fifth year. Half of the respondents $(54.3 \%)$ did not study PV at the time of the survey. Among the students that studied PV, almost a third $(26.8 \%)$ have gained basic knowledge during their pharmacology courses, whereas only $15.9 \%$ of the students have had an independent PV course. This result could explain the lack of confidence that the students expressed regarding their preparedness for ADR reporting (Table I). A dedicated mandatory PV course within the university curricula would probably allow for an in-depth study of PV and would further train pharmacy students to recognize, manage and report ADRs.

Opinion and attitudes towards ADRs reporting

Almost all students (95.7\%) strongly agreed that any pharmacy student should have basic knowledge of PV and ADRs reporting, with $95 \%$ of all considering that PV should be included in their university curricula (Table I). This is similar to results from another study where a high percentage (78\%) of students agreed that $\mathrm{PV}$ is an important topic in their education [18]. Moreover, the students surveyed agreed that postgraduate PV training could also be helpful. A recent review concluded that postgraduate PV courses, as well as the implementation of workshops or practical learning activities, are suitable to improve the knowledge of PV and preparedness in ADRs reporting [17]. Therefore, this supports the need for continuous

education in the field of PV, which is also outlined in similar studies that highlighted the importance of a proactive attitude towards ADRs reporting and active forms of learning of this topic [7, 19].

A quarter of the respondents believed (agreed/strongly agreed) that all ADRs are known before a drug is marketed. Having this belief might prevent an important percent of future pharmacist to report ARDs. However, $86.2 \%$ strongly agreed that post-marketing ADRs reporting contributes to drug risks characterization and $63 \%$ to the correct use of medicines. Among all students, $92.1 \%$ planned to report ADRs as future pharmacists, but only $48 \%$ of students in their final year and $37 \%$ in their fourth year considered themselves prepared/ready to report. Thus, the students showed a positive attitude towards ADRs reporting, similar to other studies where most of the pharmacy $(85 \%)$ and medicine $(96 \%)$ students intended to report serious ADRs $[9,17]$. Yet, this attitude is not supported by the preparedness of the students to report ADRs, which was as low as $34.8 \%$ (agree and strongly agree), in line with Saudi pharmacy students, where also only $44 \%$ stated that they are capable of reporting ADRs [1]. In our survey, the majority of respondents $(80 \%)$ considered that ADR reporting should be mandatory, as they were of the opinion that ADR reporting contributes to medicines' risks characterization, the correct use of medicines, and lastly, to the patients' safety. This opinion could also be the reason why almost all students confirmed that as future pharmacists, they plan to report ADRs encountered during their professional activity.

Table I

Opinion and attitudes towards ADRs and reporting

\begin{tabular}{|l|c|c|c|c|c|}
\hline \multicolumn{1}{|c|}{ Survey statement } & 1 = Strongly disagree & 2 = Disagree & $\mathbf{3}=$ Don't know & 4 = Agree & 5 = Strongly agree \\
\hline $\begin{array}{l}\text { 1. All ADRs are known before a } \\
\text { drug is marketed. }\end{array}$ & $55(39.9 \%)$ & $21(15.2 \%)$ & $28(20.3 \%)$ & $25(18.1 \%)$ & $9(6.5 \%)$ \\
\hline $\begin{array}{l}\text { 2. ADRs reporting contribute to } \\
\text { the knowledge of medicines' risks. }\end{array}$ & $0(0 \%)$ & $1(0.7 \%)$ & $1(0.7 \%)$ & $17(12.3 \%)$ & $119(86.2 \%)$ \\
\hline $\begin{array}{l}\text { 3. ADR reporting contributes to } \\
\text { patient safety. }\end{array}$ & $0(0 \%)$ & $0(0 \%)$ & $2(1.4 \%)$ & $10(7.2 \%)$ & $126(91.3 \%)$ \\
\hline $\begin{array}{l}\text { 4. ADR reporting contributes to } \\
\text { the correct use of medicines. }\end{array}$ & $3(2.2 \%)$ & $4(2.9 \%)$ & $14(10.1 \%)$ & $30(21.7 \%)$ & $87(63 \%)$ \\
\hline $\begin{array}{l}\text { 5. Any pharmacy student should } \\
\text { have basic knowledge of PV and } \\
\text { ADRs reporting. }\end{array}$ & $0(0 \%)$ & $0(0 \%)$ & $3(2.2 \%)$ & $3(2.2 \%)$ & $132(95.7 \%)$ \\
\hline $\begin{array}{l}\text { 6. PV should be a topic included } \\
\text { in the pharmaceutical curricula. }\end{array}$ & $2(1.4 \%)$ & $0(0 \%)$ & $5(3.6 \%)$ & $27(19.6 \%)$ & $104(75.4 \%)$ \\
\hline $\begin{array}{l}\text { 7. With my present knowledge, I } \\
\text { am well prepared to report ADRs. }\end{array}$ & $13(9.4 \%)$ & $29(21 \%)$ & $48(34.8 \%)$ & $28(20.3 \%)$ & $20(14.5 \%)$ \\
\hline $\begin{array}{l}\text { 8. As a future pharmacist, I plan } \\
\text { to report ADRs that I encounter } \\
\text { or that patients will report. }\end{array}$ & $0(0 \%)$ & $1(0.7 \%)$ & $10(7.2 \%)$ & $35(25.4 \%)$ & $92(66.7 \%)$ \\
\hline
\end{tabular}

\section{Knowledge on ADRs reporting}

Most of the students $(93.5 \%)$ knew that they could report ADRs to the National Agency for Medicines and Medical Devices of Romania (NAMMDR), and less $(37.7 \%)$ knew that they could also report to pharmaceutical companies (Table II). The percentage of students knowing that they can report to our competent authority NAMMDR is very high as compared to other studies where around half of the pharmacy $(52 \%)$ or medicine $(44 \%)$ students did not know where to 
FARMACIA, 2021, Vol. 69, 3

report ADRs [13, 17]. A possible explanation for this is that the type of questions addressing knowledge can get responses that do not represent real knowledge, but guessing using common sense, to preserve a positive self-image. Thus, an information bias cannot be excluded, and is difficult to measure and prevent. However, in our survey, there were also students choosing wrong answers, such as reporting to a professional association such as the Physicians or Pharmacists College or to the Public Health Direction (Table II). In terms of who is entitled to report ADRs, pharmacists were unanimously selected, followed by physicians $(97.1 \%)$ and patients $(82.6 \%)$.

Table II

Knowledge on ADRs reporting

\begin{tabular}{|c|c|c|}
\hline Survey-item & Answers & $\mathbf{N}(\%)$ \\
\hline \multirow{6}{*}{$\begin{array}{l}\text { 1. Where can HCPs report suspected } \\
\text { ADRs? }\end{array}$} & National Agency for Medicines and Medical Devices of Romania & $129(93.5 \%)$ \\
\hline & Pharmaceutical company & $52(37.7 \%)$ \\
\hline & Physicians or Pharmacists College & $28(20.3 \%)$ \\
\hline & Public Health Direction & $20(14.5 \%)$ \\
\hline & Any pharmacy & $2(1.3 \%)$ \\
\hline & I do not know & $1(0.7 \%)$ \\
\hline \multirow{8}{*}{$\begin{array}{l}\text { 2. Who do you believe is entitled to report } \\
\text { ADRs? }\end{array}$} & Pharmacists & $138(100 \%)$ \\
\hline & Doctors & $134(97.1 \%)$ \\
\hline & Patients & $114(82.6 \%)$ \\
\hline & Nurses & $88(63.8 \%)$ \\
\hline & Pharmacy assistants & $88(63.8 \%)$ \\
\hline & Patients' relatives & $2(1.3 \%)$ \\
\hline & Anyone & $1(0.7 \%)$ \\
\hline & Pharmaceutical companies & $1(0.7 \%)$ \\
\hline \multirow{6}{*}{$\begin{array}{l}\text { 3. For which products ADRs should be } \\
\text { reported? }\end{array}$} & Marketed human medicines & $136(98.6 \%)$ \\
\hline & Vaccines & $124(89.9 \%)$ \\
\hline & Dermatocosmetics & $118(85.5 \%)$ \\
\hline & Herbal products & $103(74.6 \%)$ \\
\hline & Medicines included in clinical trials & $97(70.3 \%)$ \\
\hline & Veterinary medicines & $87(63 \%)$ \\
\hline \multirow{7}{*}{$\begin{array}{l}\text { 4. Which of the following ADRs should } \\
\text { be reported? }\end{array}$} & Serious ADR & $130(94.2 \%)$ \\
\hline & Uncommon ADR & $126(91.3 \%)$ \\
\hline & ADR for a recently marketed medicine & $124(89.9 \%)$ \\
\hline & Unknown ADR & $124(89.9 \%)$ \\
\hline & ADR for a product with a black triangle & $81(58.7 \%)$ \\
\hline & Frequent ADR & $70(50.7 \%)$ \\
\hline & Well known ADR & $56(40.6 \%)$ \\
\hline \multirow{2}{*}{$\begin{array}{l}\text { 5. Did you ever notice a black triangle on } \\
\text { a product's leaflet or on the SmPC of } \\
\text { certain medicinal products? }\end{array}$} & No & $89(64.5 \%)$ \\
\hline & Yes & $49(35.5 \%)$ \\
\hline \multirow{7}{*}{$\begin{array}{l}\text { 6. What do you think is the meaning of } \\
\text { the black triangle used on the product } \\
\text { leaflet or on the SmPC? }\end{array}$} & I do not know & $56(40.6 \%)$ \\
\hline & The product is subject to additional monitoring & $48(34.8 \%)$ \\
\hline & There is limited data on the long-term use and safety of the product & $35(25.4 \%)$ \\
\hline & It encourages reporting of any ADR suspected for the product & $26(18.8 \%)$ \\
\hline & The product is new on the market & $14(10.1 \%)$ \\
\hline & The product is not safe & $5(3.6 \%)$ \\
\hline & Psychotropic drug & $4(2.9 \%)$ \\
\hline \multirow{5}{*}{ 7. What happens to a reported ADR? } & It is evaluated by the appropriate authorities & $115(83.3 \%)$ \\
\hline & $\begin{array}{l}\text { It is stored in EMA's ADR database, quantified and analysed } \\
\text { together with other ADRs for detecting new safety signals }\end{array}$ & $107(77.5 \%)$ \\
\hline & It is sent to the pharmaceutical company marketing the medicine & $60(43.5 \%)$ \\
\hline & It is sent to the WHO Uppsala Monitoring Center & $40(29 \%)$ \\
\hline & It is sent to the Ethics Committee & $14(10.1 \%)$ \\
\hline \multirow{6}{*}{$\begin{array}{l}\text { 8. What do you think is the purpose of } \\
\text { ADR reporting? }\end{array}$} & Patients' safety & $118(85.5 \%)$ \\
\hline & Detection of unknown ADRs & $116(84.1 \%)$ \\
\hline & Safe use of medicines & $114(82.6 \%)$ \\
\hline & Description of the safety profile of authorised medicines & $107(77.5 \%)$ \\
\hline & Detection of serious ADRs & $90(65.2 \%)$ \\
\hline & Removal of products from the market & $50(36.2 \%)$ \\
\hline
\end{tabular}

ADRs - adverse drug reactions; HCPs - healthcare professionals; EMA - European Medicines Agency; SmPC - summary of product characteristics 
FARMACIA, 2021, Vol. 69, 3

In regards to the products for which ADRs should be reported, students seemed to be confused. Most correctly identified that ADRs should be reported for marketed human medicines, vaccines and medicines included in clinical trials, but high percentages considered that ADRs should also be reported for dermatocosmetics, herbal products and veterinary medicines for which NAMMDR does not collect ADRs. This confusion may be caused by the fact that students were probably not aware that the NAMMDR only collects ADR reports for all medicinal products, including vaccines, which are approved by the agency. Herbal products and dermatocosmetics are not approved and regulated by the agency; therefore, NAMMDR does not collect ADR reports for these types of products, and for the moment in Romania, there is no dedicated reporting system for these products. This result is similar to other studies where students were not familiar with the products for which their national agencies are collecting ADR reports [9, 10].

In terms of what type of ADRs should be reported, serious ADRs (94.2\%), uncommon ADRs (91.3\%), ADRs for recently marketed medicines $(89.9 \%)$ and

unknown ADRs (89.9\%) were correctly the most selected ones. However, fewer students $(58.7 \%)$ knew that ADRs related to medicines having a black triangle symbol should be reported. Overall, more than half never noticed the black triangle on a product's leaflet or on the summary of product characteristics (with $81 \%$ of students in the fourth year and $52 \%$ in the fifth) and $40.6 \%$ did not know the meaning and purpose of the symbol (with $34.9 \%$ of the students that have studied PV).

Most of the students knew that ADRs reports are evaluated by the competent authorities (83.3\%) and stored in European Medicines Agency (EMA) ADR database to be quantified and analysed together with other ADRs with the purpose of detecting new safety signals $(77.5 \%)$. On the other hand, fewer students $(43.5 \%)$ knew that pharmaceutical companies holding the marketing authorization also would become aware of the ADR report within the European Union PV system and only $29 \%$ of the students knew that ADRs are also sent to the Uppsala Monitoring Center as part of the WHO Programme for International Drug Monitoring (Table II).

Table III

Readiness to report ADRs, related to correct knowledge on ADRs reporting, PV study and study year

\begin{tabular}{|c|c|c|c|}
\hline Readiness to report ADRs & $\begin{array}{c}\text { Yes } \\
(\mathrm{n}=48)\end{array}$ & $\begin{array}{c}\text { No } \\
(\mathrm{n}=90)\end{array}$ & P-value \\
\hline \multicolumn{4}{|l|}{ Where can HCPs report suspected ADRs? } \\
\hline National Agency for Medicines and Medical Devices of Romania & $47(97.92)$ & $82(91.11)$ & 0.162 \\
\hline Pharmaceutical company & $22(45.83)$ & $30(33.33)$ & 0.149 \\
\hline Fully correct answer (all multiple choices answers correctly selected) & $13(27.08)$ & $15(16.67)$ & 0.147 \\
\hline \multicolumn{4}{|l|}{ For which products ADRs should be reported? } \\
\hline Marketed human medicines & $48(100)$ & $88(97.78)$ & 0.543 \\
\hline Vaccines & $46(95.83)$ & $78(86.67)$ & 0.138 \\
\hline Medicines included in clinical trials & $30(62.5)$ & $67(74.44)$ & 0.144 \\
\hline Fully correct answer (all multiple choices answers correctly selected). & $0(0)$ & $8(8.89)$ & 0.05 \\
\hline \multicolumn{4}{|l|}{ Which of the following ADRs should be reported? } \\
\hline Serious ADR & $45(93.75)$ & $85(94.44)$ & 1 \\
\hline Uncommon ADR & $42(87.5)$ & $84(93.33)$ & 0.341 \\
\hline ADR for a recently marketed medicine & $43(89.58)$ & $81(90)$ & 1 \\
\hline Unknown ADR & $40(83.33)$ & $84(93.33)$ & 0.079 \\
\hline ADR for a product with a black triangle & $31(64.58)$ & $50(55.56)$ & 0.305 \\
\hline Fully correct answer (all multiple choices answers correctly selected) & $12(25)$ & $16(17.78)$ & 0.315 \\
\hline \multicolumn{4}{|c|}{ What do you think is the meaning of the black triangle used on the product leaflet or on the SmPC? } \\
\hline The product is subject to additional monitoring & $20(41.67)$ & $28(31.11)$ & 0.215 \\
\hline There is limited data on the long-term use and safety of the product & $12(25)$ & $23(25.56)$ & 0.943 \\
\hline It encourages reporting of any ADR suspected for the product & $11(22.92)$ & $15(16.67)$ & 0.371 \\
\hline The product is new on the market & $3(6.25)$ & $11(12.22)$ & 0.379 \\
\hline Fully correct answer (all multiple choices answers correctly selected) & $12(25)$ & $16(17.78)$ & 0.315 \\
\hline \multicolumn{4}{|l|}{ Students characteristics } \\
\hline Students that studied pharmacovigilance & $30(62.5)$ & $33(36.67)$ & 0.004 \\
\hline Students in their $4^{\text {th }}$ and $5^{\text {th }}$ study year & $34(70.83)$ & $47(52.22)$ & 0.034 \\
\hline
\end{tabular}

ADRs - adverse drug reactions; HCPs - healthcare professionals; PV - pharmacovigilance

We assessed weather knowledge on ADR reporting was associated with the preparedness/ readiness to report ADRs in order to see if pharmacy students that considered themselves ready to report have better knowledge than those who don't. Therefore, we grouped students that agreed and strongly agreed with the statement that "With my present knowledge, I am well prepared to report ADRs" as students ready to report $(\mathrm{n}=48)$, and those that didn't know, disagreed and strongly disagreed as students not ready to report $(\mathrm{n}=$ 
90, Table III). Then, we compared these groups to see if they answered correctly to questions 1, 3, 4 and 6 from Table II, as we considered that these questions are directly related to the performance of the spontaneous reporting system in Romania. Next, we have also checked to see whether the fact that students studied pharmacovigilance or if they were in their final study years $\left(4^{\text {th }}\right.$ and $\left.5^{\text {th }}\right)$ could influence the readiness to report. We couldn't find any significant statistical difference in terms of knowledge between the students that considered themselves ready to report, compared to those who don't. However, students that studied pharmacovigilance and the ones in their final study

years $\left(4^{\text {th }}\right.$ and $\left.5^{\text {th }}\right)$ considered themselves more prepared to report as compared with those who didn't study pharmacovigilance and the ones in the first three years of study $(p=0.004$ and $p=0.034)$. To further explore these relations, we performed a multiple linear regression predicting the mean percentage of correct answers to the four selected questions. The regression results also support the fact that studying PV will favour readiness to report ADRs (Table IV). These results are outlining the need for PV training during the study years in order for students to feel that they can contribute with their knowledge to the national spontaneous reporting system.

Table IV

Factors influencing readiness to report ADRs (multiple linear regression results predicting the mean percentage of correct answers to the four selected questions)

\begin{tabular}{|l|c|c|c|c|c|c|}
\hline \multicolumn{1}{|c|}{ Characteristic } & B unadjusted & $(95 \% \mathrm{CI})$ & $\mathrm{p}$ & $\mathrm{B}$ adjusted & $(95 \% \mathrm{CI})$ & $\mathrm{p}$ \\
\hline Students that studied pharmacovigilance & 2.55 & $(-0.27-5.36)$ & 0.078 & 3.38 & $(0.33-6.43)$ & $\mathbf{0 . 0 3 2}$ \\
\hline Students in their $4^{\text {th }}$ and $5^{\text {th }}$ study year & 0.17 & $(-2.73-3.06)$ & 0.911 & -1.41 & $(-4.5-1.69)$ & 0.375 \\
\hline Gender (female) & -2.93 & $(-8.73-2.87)$ & 0.323 & -3.88 & $(-9.98-2.22)$ & 0.214 \\
\hline
\end{tabular}

ADRs - adverse drug reactions; B - regression unstandardized coefficient

Pharmacy students mostly believed that the purpose of ADR reporting is patient safety $(85.5 \%)$, detection of unknown ADRs (84.1\%) and the safe use of medicines $(82.6 \%)$ (Table II).

Safe use of medicines, aside from patients' safety, is in fact, results of timely ADR detection and reporting, which allow the implementation of risk minimization measures. These risk minimization measures most often consist of updating prescription recommendations, including restriction of indications, prescribing lower dosages or reducing the treatment duration, adding new contraindications or precautions for drug use, and adding new, previously unknown ADRs or changing the frequency category of a known ADR. Consistent with this, almost all students participating in our survey correctly knew that ADR reporting could lead to a change in the prescription information of a medicine (96.4\%).

On the other hand, one-third of the students considered incorrectly that one of the purposes of ADR reporting is the withdrawal of medicines. This is definitely not the purpose of ADRs reporting. These days, medicines withdrawal from the market is one of the last measures that competent authorities employ, only in the cases when the measures taken to reduce the risks are unsuccessful and therefore no other option to mitigate the risks exists.

These risk mitigation strategies allow for the implementation of new safety measures by the appropriate authorities in Europe or in the USA. But for the authorities to be able to detect safety signals and to employ risk minimization measures whenever these signals are confirmed, reporting ADRs within the spontaneous reporting system is of utmost importance. In the last years, the majority of safety signals were generated by spontaneous ADR reporting. The safety signals detected were both for recent and old medicines [14]. This highlights the need for serious ADR reporting for all drugs, as new risks can be identified for new medicines, but also for old, frequently used medicines. Identifying new risks for older medicines could also point out changes in the prescription practices of a certain medicine over time or to a better organization of the safety monitoring systems in the last years.

The pharmacists' involvement in ADR reporting systems, especially of community pharmacists, is very important. However, among the barriers to ADRs reporting, lack of time (46\%) and community pharmacists' perception that an ADR is not always serious enough to report $(65 \%)$ were identified in the UK [6]. This outlines the need for education on PV and its importance again. Continuous education and training for HCPs on PV, as well as inter-professional collaboration, have proved to be very beneficial for improving their abilities in PV and ADRs reporting [19]. PV is an extensive field that requires a vast knowledge of pharmacology, pharmacokinetics, IT/biostatistics and legislation [2]. With this in mind, it is considered that a practical approach when studying PV during their years of studies helps students to gain more knowledge than through a passive approach $[2,5$, 17, 19].

\section{Conclusions}

Overall, the results of the survey indicated that Romanian pharmacy students have basic knowledge and positive attitudes towards ADRs reporting.

However, less than half of the students considered themselves prepared to report; therefore, future educational initiatives should be targeted to address this aspect. 
Conflict of interest

The authors declare no conflict of interest.

\section{References}

1. Alkayyal N, Cheema E, Hadi MA, Perspective of Saudi undergraduate pharmacy students on pharmacovigilance and adverse drug reaction reporting: A National Survey. Curr Pharm Teach Learn, 2017; 9(5): 779-785.

2. Beckmann J, Hagemann U, Bahri P, Bate A, Boyd IW, Dal Pan GJ, Edwards BD, Edwards IR, HartiganGo K, Lindquis M, McEwen J, Moride Y, Olsson S, Pal SN, Soulaymani-Bencheikh R, Tuccori M, Vaca $\mathrm{CP}$, Wong ICK, Teaching Pharmacovigilance: the WHO-ISoP Core Elements of a Comprehensive Modular Curriculum. Drug Saf., 2014; 37(10): 743-759.

3. Bouvy JC, De Bruin ML, Koopmanschap MA, Epidemiology of Adverse Drug Reactions in Europe: A Review of Recent Observational Studies. Drug Safety, 2015; 38(5): 437-453.

4. Bucșa C, Bulik N, Farcaș A, Mureșan S, Mureșan I, Oniga $\mathrm{O}$, Adverse events following measles-mumpsrubella vaccination. A prospective observational study. Farmacia, 2020; 68(2): 219-222.

5. Cerbin-Koczorowska M, Przymuszała P, Michalak M, Piotrowska-Brudnicka SE, Kant P, Skowron A, Comparison of medical and pharmacy students' readiness for interprofessional learning - A cross-sectional study. Farmacia, 2020; 68(6): 1166-1172.

6. Cheema E, Haseeb A, Khan TM, Sutcliffe P, Singer DR, Barriers to reporting of adverse drugs reactions: A cross sectional study among community pharmacists in United Kingdom. Pharm Pract., 2017; 15(3): 1-7.

7. Christensen ST, Søndergaard B, Honoré PH, Bjerrum OJ, Pharmacy student driven detection of adverse drug reactions in the community pharmacy setting. Pharmacoepidemiol Drug Saf., 2011; 20(4): 399-404.

8. Elkalmi RM, Hassali MA, Ibrahim MIM, Widodo RT, Efan QMA, Hadi MA, Pharmacy students' Knowledge and perceptions about pharmacovigilance in Malaysian public universities. Am J Pharm Educ., 2011; 75(5): $1-8$.

9. Gavaza P, Bui B, Pharmacy students' attitudes toward reporting serious adverse drug events. Am J Pharm Educ., 2012; 76(10): 1-6.

10. Hadi MA, Neoh CF, Zin RM, Elrggal M, Cheema E, Pharmacovigilance: pharmacists' perspective on spontaneous adverse drug reaction reporting. Integr Pharm Res Pract., 2017; 6: 91-98.
11. Hartman J, Härmark L, van Puijenbroek E, A global view of undergraduate education in pharmacovigilance. Eur J Clin Pharmacol., 2017; 73(7): 891-899.

12. Hazell L, Shakir SAW, Under-Reporting of Adverse A Systematic Review. Drug Saf., 2006; 29(5): 385-396.

13. Osemene KP, Afolabi MO, An evaluation of the knowledge and perceptions of pharmacy students on pharmacovigilance activities in Nigeria. BMC Res Notes, 2017; 10(1): 1-9.

14. Pacurariu AC, Coloma PM, van Haren A, Genov G, Sturkenboom MCJM, Straus SMJM, A Description of Signals during the First 18 Months of the EMA Pharmacovigilance Risk Assessment Committee. Drug Saf., 2014; 37(12): 1059-1066.

15. Rajiah K, Maharajan MK, Nair S, Pharmacy students' knowledge and perceptions about adverse drug reactions reporting and pharmacovigilance. Saudi Pharm J., 2016; 24(5): 600-604.

16. Activity report 2017 of the National Agency for Medicines and Medical Devices, 28 May 2020, www.anm.ro/_/raport activitate/raport de activitate ANMDM 2017.pdf, (available in Romanian).

17. Reumerman M, Tichelaar J, Piersma B, Richir MC, van Agtmael MA, Urgent need to modernize pharmacovigilance education in healthcare curricula: review of the literature. Eur J Clin Pharmacol., 2018; 74(10): 1235-1248.

18. Schutte T, Tichelaar J, Reumerman MO, van Eekeren R, Rissmann R, Kramers C, Richir MC, van Puijenbroek EP, van Agtmael MA, Keijsers K, van Molkot F, Pharmacovigilance Skills, Knowledge and Attitudes in our Future Doctors - A Nationwide Study in the Netherlands. Basic Clin Pharmacol Toxicol., 2017; 120(5): 475-481.

19. Schutte T, Tichelaar J, Reumerman MO, van Eekeren R, Rolfes L, van Puijenbroek EP, Richir MC, van Agtmael MA, Feasibility and Educational Value of a Student-Run Pharmacovigilance Programme: A Prospective Cohort Study. Drug Saf., 2017; 40(5): 409-418.

20. van Eekeren R, Rolfes L, Koster AS, Magro L, Parthasarathi G, Al Ramimmy H, Schutte T, Tanaka D, van Puijenbroek E, Härmark L, What Future Healthcare Professionals Need to Know About Pharmacovigilance: Introduction of the WHO PV Core Curriculum for University Teaching with Focus on Clinical Aspects. Drug Saf., 2018; 41(11): 1003-1011.

21. van Grootheest AC, de Jong-van den Berg LTW, The role of hospital and community pharmacists in pharmacovigilance. Res Soc Admin Pharm., 2005; 1(1): 126-133. 